УДК 159.9

\section{С.А. Гришаева \\ П.Н. Сойникова}

Svetlana Grishaeva

Polina Soynikova

\section{ФОРМИРОВАНИЕ ИМИДЖА ПОЛИТИЧЕСКОГО ЛИДЕРА В СОЦИАЛЬНОЙ СЕТИ INSTAGRАМ}

Аннотация. Рассмотрена типология имиджей в современной политической психологии. Исследован аккаунт Главы Чеченской Республики P. A. Кадырова в Instagram на основе содержания его публикаций за определенный отрезок времени и обозначен сформированный имидж. Выделяя основные имиджеообразуюшие векторы в Instagram-аккаунте P.A. Кадырова, стоит сказать о его выступлениях в поддержку нынешней власти и Президента РФ, реагировании на резонансные международные проблемь, трансляции в массы идеи патриотизма на региональном и федеральном уровнях, популяризации института семьи, пропаганде спорта. Ключевые слова: политический лидер, Рамзан Кадыров, имидж, Instagram, сочиальная сеть, Чеченская Республика.

\title{
FORMATION OF THE IMAGE OF A POLITICAL LEADER IN THE SOCIAL NETWORK INSTAGRAM
}

Annotation. The image of the typology in modern political psychology is considered.
The content of publications for a certain period in the profile of the Head of the Che-
chen Republic R. A. Kadyrov in Instagram was studied. The formed image is signified.
Emphasizing the main vectors of image constructing in the Instagram account of R.
A. Kadyrov, is to say about his speeches in support of the current government and the
President of the Russian Federation, how he responds to high-profile international
issues, broadcasts to the masses the ideas of patriotism at the regional and Federal
levels and promotes the institution of family and the promotion of sport.
Keywords: political leader, Ramzan Kadyrov, image, Instagram, social network,
Chechen Republic.

В процессе информатизации общества все большее влияние приобретают социальные сети. Использование их ресурсов стремительно растет как среди рядовых пользователей, так и среди видных политических фигур. Особое внимание роли социальных сетей уделяют политические лидеры, используя их для создания и поддержания своего имиджа, а также для коммуникации с целевой аудиторией и информирования о своей деятельности всех пользователей социальных сетей. В российском сегменте интернет-пространства имеется широкий ряд отечественных и зарубежных социальных сетей, которые предназначены как для широкой аудитории, так и для узкой группы лиц, формируемой по определенному признаку. Сами социальные сети, помимо иных различий, отличаются друг от друга визуальными способами и стилем демонстрации материалов, возможностью эффективного показа опубликованного материала другим пользователям, которые еще не подписаны на автора.

Одной из наиболее популярных социальных сетей современности является Instagram - социальная сеть для обмена и оценки фотографий и коротких видеороликов [4]. Многие видные зарубежные и отечественные политики имеют собственный аккаунт в Instagram и регулярно «наполняют его новой информацией», публикуя для своей аудитории актуальный контент, путем размещения фото и видео материалов, а также посредствам онлайн-трансляций. Среди российских политических лидеров одним из активных пользователей Instagram, с аудиторией в 3,2 млн подписчиков, выступает Глава Чеченской Республики Рамзан Ахматович Кадыров. Его аккаунт ведется в едином стиле, отражающем имидж и основные посылы Главы Чеченской Республики.

(C) Гришаева С.А., Сойникова П.Н., 2017 
Актуальность тематики исследования обусловлена тенденцией роста и развития использования социальных сетей в качестве политико-психологического инструмента политических лидеров и власти для реализации своих разнонаправленных целей и задач, распространяющихся на широкую интернетобщественность, в том числе целей и задач по эффективному формированию и поддержанию собственного имиджа. Сообразно актуальности, основной целью работы выступает рассмотрение и определение имиджа политического лидера Р. А. Кадырова в рамках его аккаунта в социальной сети Instagram. Для реализации цели необходимо выполнить ряд задач:

1) рассмотреть имиджевую типологию и личностные теории, применимые в пространстве социальной сети;

2) исследовать Instagram-профиль Р. А. Кадырова на предмет выявления имиджеобразующих составляющих;

3) охарактеризовать влияние профиля Рамзана Кадырова на формирование его имиджа в восприятии других пользователей Instagram.

Над проблемой имиджа в российской политической науке работал ряд исследователей, таких как Г. Г. Почепцов, Е. В. Егорова-Гантман, Е. Б. Шестопал, К. В. Плешаков, Е. Б. Перелыгина и многие другие. Г. Г. Почепцов определяет имидж как многофакторный феномен, т.к. с одной стороны, «воздействие на человека осуществляется по ряду каналов, а с другой - человек привык оперировать многослойными структурами» [2, с. 311]. В силу многофакторности имидж можно разложить на самоимидж, воспринимаемый имидж, требующий имидж, каждый из которых формируется посредством ряда внешних и внутренних факторов, как полагает английская исследовательница Элери Сэмпсон, чьи слова Почепцов приводит в своей работе [2, с. 36]. Обращаясь к рассмотрению типологии имиджа, Почепцов отмечает, что «современная наука выделила такие типы имиджей как зеркальный - наше представление о себе, текущий - взгляд и мнение внешней публики, желаемый - имидж, к которому стремимся, корпоративный имидж организации в целом, множественный - имидж компании» [2, с. 37].

Имидж, как реальный, так и виртуальный, помимо основного вектора развития, для целостного формирования должен учитывать необходимость контекста, в котором осуществляется позиционирование. Г. Г. Почепцов выделяет ряд факторов: прошлое, семья, спорт, домашние животные, хобби [2, с. 312]. Эти факторы могут варьироваться, усиливаться или нивелироваться в зависимости от потребностей имиджа и целевой аудитории. Индивиды как потенциальный электорат и политики имеют в качестве линии связи политический имидж. Анализируя имидж в социальных сетях, целесообразно применить семиотический подход, так, например, Е. Б. Перелыгина в своей работе «Психология имиджа» приводит классификацию Ч. С. Пирса, который разделил знаки на естественные (знаки-индексы), иконические (знаки-образы) и символические (знаки-символы) [1, с. 29]. Актуальность имеют символические и иконические знаки в их искусственном происхождении, в случае их перевода в цифровую среду социальных сетей, в виде фотографий и языка Еmојі. Таким образом, в силу использования в имидже не единичных знаков, а комплексного их использования, позволительно будет назвать имидж знаковой структурой, которую воспринимает целевая аудитория [1, с. 34].

Восприятие имиджа напрямую зависит от типа личности индивида. На наш взгляд, К. Г. Юнг отразил наиболее оптимальный вариант классификации, опираясь на то, как разные индивиды видят мир. Он выделил восемь типологических групп: две личностные установки (интроверсия и экстраверсия) и четыре функции или типа ориентации - мышление, ощущение, интуицию, чувство [3, с. 8]. Актуальной личностной установкой целевой аудитории для трансляции имиджа выступает экстраверсия. Шарп приводит цитату Юнга, где тот дает определение экстраверсии и объясняет сущность экстраверта: «Человек такого типа придает решающую силу объективной действительности, или, соответственно, ее объективно ориентированной интеллектуальной формуле, - и притом не только по отношению к самому себе, но и по отношению к социальной среде» [3, с. 38]. При этом политический лидер, который транслирует собственный 
имидж на аудиторию, может быть как экстравертом, так и интровертом. Рассматривая это в плоскости социальных сетей, можно предположить, что разница этих установок нивелируется и сложно сразу определить, какой человек ведет аккаунт. Различие можно обнаружить, изучив аккаунт индивида на предмет тематики, стилистики контента, частоты публикаций и сопровождающего текста.

Глава Чечни Рамзан Ахматович Кадыров - активный пользователь социальной сети Instagram, его аккаунт «kadyrov_95" насчитывает, согласно данным его личного профиля, 10052 публикации, 3,2 млн подписчиков, что могло бы дать ему статус СМИ в случае возобновления законодательного регулирования данного аспекта [5].

Название аккаунта подобрано в официальной стилистике - фамилия политика и автомобильный код региона, что свидетельствует о его желании подчеркнуть принадлежность к Чеченскому региону. Фото профиля периодически меняется: на данный момент - это Президент Российской Федерации Владимир Владимирович Путин за телефонным разговором. В описании профиля указано следующее «Любите Пророка (aلdwadc) ламу [5]. Нами были рассмотрены публикации, размещенные в период с 1 по 30 ноября 2017 года. Всего за указанный период было размещено 106 публикаций, из них 13 фотографий и 96 видеозаписей, также ежедневно размещаются «stories».

Детально изучив публикации Рамзана Кадырова за указанный промежуток времени, необходимо обозначить ряд основных векторов в ведении аккаунта. Значительное место в публикациях занимает Президент Российской Федерации - Владимир Владимирович Путин. В аккаунте выкладываются изображения и видеоматериалы с его участием, а также аудиосопровождение видеоматериалов его цитатами, использовано 20 раз; отчеты о работе Правительства, развитии социальноэкономических сфер в Чечне встречаются 22 раза; спортивная тематика затрагивается около 17 раз, фрагментарно показаны в видеозаписях спортивные интересы Кадырова, его детей и друзей; видеозаписи религиозного характера встречаются 10 раз; упоминание о семейных ценностях встречается неоднократно, семья Р. А. Кадырова и его дети показаны 6 раз; во многих публикациях присутствует патриотический посыл, в чистом виде идея патриотизма встретилась 6 раз.

Доминирующей составляющей в опубликованном контенте за ноябрь оказались поздравления - 34 раза. Из этих 34 публикаций встречаются как поздравления по случаю профессиональных праздников, так и адресованные конкретным людям. Интересен тот факт, что преимущественно Рамзан Кадыров поздравляет жителей своего региона, используя в видео фразу «С Днем Рождения!» на чеченском языке - «Винчу Денца!», но при этом, поздравляя персон федерального масштаба, использует русскоязычный вариант этой фразы.

В среднем в день Р. А. Кадыров делает 3-4 публикации. Возможность комментировать доступна другим пользователям социальной сети. Стоит отметить, что на размещенных видеозаписях в левом верхнем углу имеется лейбл, которым Кадыров маркирует видеоматериалы в своем аккаунте, также внимание привлекает качество съемки и монтажа видео, что может свидетельствовать о работе над этим аккаунтом ряда специалистов. Текстовой контент (подписи под публикациями) имеют ярко выраженную личностную окраску, довольно часто можно встретить обращение «брат», личные поздравления ряда чиновников с днем рождения, отклик Кадырова на проблемы своего региона и ответы в формате «по моему распоряжению» и других подобных формах. В материалах, публикуемых в аккаунте Кадырова, очень большое место отведено идее патриотизма как регионального, так и федерального уровней [7].

Выделяя основные имиджеообразующие векторы в Instagram-аккаунте Рамзана Ахматовича Кадырова, стоит сказать о его выступлениях в поддержку нынешней власти и Президента РФ, реагировании на резонансные международные проблемы, трансляции в массы идеи патриотизма на региональном и федеральном уровнях, популяризации института семьи, пропаганде спорта. 
Можно сделать вывод о его позиционировании себя как экстраверта, дружелюбного «своего» человека, увлеченного спортом, семьей, озабоченного благополучием граждан, развитием своего региона и страны в целом. Соответствующий образ политика положительно отражается на формировании его имиджа в восприятии других пользователей социальной сети Instagram. В комментариях пользователей было обнаружено множество положительных откликов и просьб людей о различных видах помощи. Благодаря грамотной работе по ведению профиля политического лидера в контексте традиционного лидерства, Рамзан Кадыров сформировал устойчивый имидж лидера, опирающегося на традиционные ценности общества.

\section{Библиографический список}

1. Перелыгина, Е. Б. Психология имиджа : учеб. пособ. / Е. Б. Перелыгина. - М. : Аспект Пресс, 2002. - 221 с.

2. Почепцов, Г. Г. Имиджелогияю - 2. изд., испр. и доп. / Г. Г. Почепцов. - М. : Рефл-бук : Ваклер, 2001. - 698 с.

3. Психологические типы. Юнгиантская типологическая модель / перевод Дэрил Шарп. - Москва : Ин-т общегуманитарных исследований, 2016. - 189 с.

4. Instagram [Электронный ресурс]. - Режим доступа : https://ru.wikipedia.org/wiki/Instagram (дата обращения: 30.11.2017).

5. Instagram-аккаунт Р. А. Кадырова [Электронный ресурс]. - Режим доступа : https://www.instagram.com/kadyrov_95/?hl=ru (дата обращения : 30.11.2017).

6. Instagram-аккаунт P. А. Кадырова, отдельная публикация [Электронный ресурс]. https://www.instagram.com/p/BbkMLrSHNEW/?hl=ru\&taken-by=kadyrov_95 (дата обращения : 30.11.2017)

7. Lenta.ru [Электронный ресурс]. - Режим доступа : https://lenta.ru/news/2016/02/03/putin/ (дата обращения : 30.11.2017)

\section{References}

1. Perelygina E. B. Psihologija imidzha [Psychology of Image]. Moscow, Aspekt Press, 2002. 221 p.

2. Pochepcov G. G. Imidzhelogija [Imagology]. Moscow, Refl-buk, Vakler, 2001. 698 p.

3. Psihologicheskie tipy. Jungiantskaja tipologicheskaja model' [Psychological Types. The Jungian Psychological Model]. Moscow, Institute of educational research, 2016. 189 p.

4. Instagram. Available at: https://ru.wikipedia.org/wiki/Instagram (Accessed: 30 November 2017).

5. Instagram profile of R. A. Kadyrov. Available at: https://www.instagram.com/kadyrov_95/?hl=ru (accessed: 30 November 2017).

6. Instagram profile of R. A. Kadyrov, single post. Available at: https://www.instagram.com/p/BbkMLrSHNEW/?hl=ru\&taken-by=kadyrov_95 (Accessed: 30 November 2017).

7. Lenta.ru. Available at: https://lenta.ru/news/2016/02/03/putin/ (Accessed: 30 November 2017). 